\title{
Article
}

\section{Realising Sedgwick's Vision: Theorising strategies of resistance to neoliberal mental health policy}

Moth, Rich and Mckeown, Michael

Available at http://clok.uclan.ac.uk/15301/

Moth, Rich and Mckeown, Michael ORCID: 0000-0003-0235-1923 (2016)

Realising Sedgwick's Vision: Theorising strategies of resistance to neoliberal mental health policy. Critical and Radical Social Work, 4 (3). pp. 375-390. ISSN 2049-8608

It is advisable to refer to the publisher's version if you intend to cite from the work.

http://dx.doi.org/10.1332/204986016X14721364317690

For more information about UCLan's research in this area go to http://www.uclan.ac.uk/researchgroups/ and search for <name of research Group>.

For information about Research generally at UCLan please go to http://www.uclan.ac.uk/research/

All outputs in CLoK are protected by Intellectual Property Rights law, including Copyright law. Copyright, IPR and Moral Rights for the works on this site are retained by the individual authors and/or other copyright owners. Terms and conditions for use of this material are defined in the policies page.

\section{CLoK}

Central Lancashire online Knowledge www.clok.uclan.ac.uk

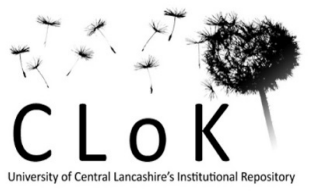




\section{Realising Sedgwick's Vision: Theorising strategies of resistance to neoliberal mental health policy}

\section{Abstract}

There has recently been a re-emergence of interest in non-reductive historical materialist modes for analysing social movements. A precursor of this is found in the work of mental health activist and Marxist theorist Peter Sedgwick. We contend that Sedgwick's work retains utility for theorising radical mental health movements in the twenty-first century, though we argue his framework needs extension in light of intervening debates regarding the interaction of material (distributive) and post-material (recognition) concerns. Having established this we will turn to an overview of recent neoliberal work, welfare and mental health policy reforms as a basis for consideration of strategic implications and challenges for resistance and coalition building amongst survivor and worker activists. We will propose a contemporary Sedgwickian strategy that identifies transitional organizing goals combining concrete material demands with imaginative, prefigurative means oriented towards ruptural change. In conclusion we argue that tools for promoting this strategy such as the Social Work Action Network's (SWAN) Mental Health Charter may assist in binding together diverse constituencies to strengthen alliances of resistance and deepen a politics of solidarity.

Keywords: mental health; social movements; Marxism; welfare reform; psycho-compulsion; strategies of transformation 


\section{Introduction}

Limitations of the discursive and cultural turn in social and political analysis are latterly apparent. While a positive contribution is acknowledged, overreliance on constructivist critiques has arguably undermined engagement with pressing contemporary concerns. Hence, a case can be made for reorientating activism towards material needs and attending to social class which have arguably recently been de-emphasised across academic and activist circles. Consequently, our critique chimes with a renewal of political interest in historical materialist approaches to social movement theorising (Barker and Lavalette, 2015; Barker et al, 2013; Creaven, 2007).

The field of mental health provision and activism is one substantive domain in which this re-emergent mode of analysis may prove productive. Such a project is arguably aided by critical re-engagement with the Marxist materialist methodology developed by Peter Sedgwick, informed by his engagement in mental health and wider social and political struggles from the 1960s to 1980s. While Sedgwick did not seek to develop a comprehensive materialist theory of mental distress per se, he articulated a powerful political and epistemological critique of the prominent biomedical and radical antipsychiatric theories of his time via a nuanced and non-reductive historical materialist framework. We concur with Pilgrim (2016) that Sedgwick's materialist orientation is consistent with the stratified, depth ontology of critical realism $(\mathrm{CR})$, and the epistemological perspective of $\mathrm{CR}$ underpins the materialist framework developed in this paper. Moreover Sedgwick's approach was typically characterized by detailed elaboration of concrete tendencies and potentials within a specific conjuncture. We share this concern to integrate both theory and practice.

\section{Sedgwick's Political Methodology}

While Sedgwick does not engage anywhere in detailed articulation of his methodology it is possible to trace its broad outline. Foremost is critical engagement with positivist psychiatry and the anti-psychiatry movement, with which he was a contemporary interlocutor (Sedgwick, 1982a; 1982b/2015). 
Sedgwick acknowledges the partia/ validity of the anti-psychiatric contention that, "in uncovering the factual, objective basis of psychopathology ... [positivist psychiatrists] have forgotten the subjective valuations which impregnate their whole enterprise" (Sedgwick, 1982b: 26). Consequently he concurs with the proposition that mental illness is a social construction but recognizing this "may be put in either a strong or weak form" (Sedgwick, 1982a: 200). Sedgwick identifies with the 'weak' version, proposing a more integrative epistemology evocative of critical realism (Pilgrim, 2013) that navigates a course between the reductionist extremes of 'hard' social constructionism, and forms of bio-medical essentialism.

For Sedgwick, a scholarly concern with epistemological rigour is a necessary though not sufficient condition for a methodology tasked with developing critical understandings of both psychiatry and the wider society from which it emerges. This requires what Cresswell and Spandler (2009) have termed a 'political epistemology'. Thus, Sedgwick highlights the failure of anti-psychiatric critiques to provide an epistemological and theoretical vantage point from which to problematize New Right welfare retrenchment or consider alternative collective forms of provision for those experiencing mental distress.

Moreover, Sedgwick understands the political in its wider sense of collective and individual agency directed to maintaining or transforming social structures. The application of this mode of analysis to psychiatry and systems of mental health support involves understanding these institutions and practices as emergent from particular structural and political pre-conditions:

[I]nnovation and reform in psychiatry have always been linked with the arrival of certain conditions of political possibility ... variously either promoted or blocked by ideological tendencies and social movements (Sedgwick, 1987: 205).

While rejecting economic determinism, he nonetheless considered analysis of the political and economic dynamics of capitalism as essential for understanding welfare settlements relating to mental health, specifically how such structures 
afford particular historically contingent enablements and constraints to the agency of various individual and collective social actors.

Sedgwick rejected a reductionist orientation solely to questions of resource allocation, arguing for a progressive politics of mental health that transcends this. Though questions of how much service provision are vital, Sedgwick (1987: 194) counsels consideration of what kind of welfare services we need. Similarly, campaigns to defend services may avoid questioning unequal power relations between practitioners and service users, or obscure recognition of wider sociopolitical determinants of health and associated public mental health measures. Hence Sedgwick's (1972) plea for 'more and better' services.

Finally transformative change, for Sedgwick, requires development of a politics that integrates diverse demands of service user/survivors, mental health workers and the wider public. He viewed construction of 'crosssectional' alliances between these groups including carers and, crucially, trade unions, as vital. Without underestimating the inherent challenges and complexities, he proposed development of demands on the state, informed by radically progressive movement values, as a means to create conditions favourable to alliance building. Within this the organised Left would have an essential role in integrating demands 'from below' for collective public welfare provision. He proposed these cross-sectional demands should take a 'transitional' form, urging government to meet pressing concrete needs experienced by wide layers of the population but denied by current political priorities and funding arrangements. Alongside, and perhaps to some degree in tension with this, he argued that the models of support demanded should pre-figure more fundamentally democratic and mutual social futures which these transformative political movements sought to realise (Sedgwick, 1987).

Since Sedgwick's (1982a) Psycho Politics was published diverse theoretical orientations have attempted to make sense of contestation, social movements and their relationship to welfare settlements, often emphasizing supposed divisions between class-based 'old' welfare movements focused on economic redistribution and 'new' social movements (NSM) more oriented to culture and identity. Theorists such as Melucci (1996) argue that NSMs have superseded 
organised labour which was demobilised on achievement of welfare state goals. Consequently, concerns with 'identity' supplanted those of 'interest', and a theoretical focus on subjectivity, language and collective identity formation predominated (Krinsky, 2013) underpinned by a strong constructivism (Boucher, 2008). NSM theorists were justified in their critique of crude materialist approaches that reduce the linguistic and discursive to mere epiphenomena of economic structures. Yet, certain of these critiques arguably risked throwing out the more nuanced 'baby', connecting social-structural locations and particular forms of social and political consciousness or interest, with the 'bathwater' of materialist essentialism (Steinmetz, 1994). Edwards (2004 p. 114) concurs, arguing that in the context of neoliberal transformations and renewed forms of anti-capitalist and militant trade union activism there is an integration and imbrication of post-material issues of identity with concerns related to distribution and production.

The challenge for (historical) materialist accounts of mental health movements has thus been to present a credible non-determinist account of material interests in socio-political context that does not efface issues of recognition and subjugation. For instance the most prominent personal experience of many survivors is the substantial oppression flowing from psychiatry. Hence, it is understandable that the mental health system and its professionals are frequently viewed as primary targets for critique. Arguably, as a result of this experiential orientation, wider structural and distributive concerns related to class have tended to be de-emphasised, discounted or subsumed amidst myriad intersecting spheres of disadvantage.

Emergent tendencies within current radical survivor movements, however, reassert materialist concerns with redistribution whilst simultaneously attending to post-material issues of recognition/oppression. For instance, while McKenna (2016) notes the continuing salience of oppressive aspects of psychiatry she argues that, for survivors, the sharp edge of lived experience has shifted to the troubling impacts of welfare reform (see also Recovery in the Bin, 2016). To understand these emergent integrative political orientations, it is necessary to engage in a more detailed exposition of the 
changing nature of welfare.

\section{Mental health, welfare and work under neoliberalism}

The next stage in our argument is to elaborate the dynamics of the welfare system in its wider social and political context. Our particular focus is reconfiguration of the relationship between mental health provision, welfare and labour markets under neoliberalism. We identify two notable and interrelated structural tendencies in this policy arena. First the re-commodification of welfare claimants' labour power, by orienting policy towards 'return to work' and away from longer-term mental health service provision, thereby subordinating the needs of relevant welfare recipients to the requirements of capital accumulation (Grover and Piggott, 2005). The contemporary labour markets with which people are being compelled to re-engage are, moreover, frequently toxic for mental health as a result of the second structural mechanism we will outline: the reconfiguration and intensification of work under neoliberalism.

An important dimension of the neoliberal political project has been restructuring of the welfare state. For neoliberal policymakers the interaction between labour markets and welfare regimes is an increasingly important concern. This often starts with an assessment that welfare provision has decreased workers' dependence on the labour market resulting in disincentives to seek paid work (Esping-Anderson, 1990), in turn reducing labour supply, pushing up its cost (Grover and Soldatic, 2013). Consequently, in order to increase supply and types of labour power available for capitalist production and accumulation, recent policy has urged 'putting people to work' (Grover and Soldatic, 2013).

This agenda has particularly targeted welfare claimants in receipt of disability benefits (Grover, 2015). Such individuals constitute a so-called 'reserve army of labour', prepared to work for relatively low wages (Grover, 2003). To facilitate individuals' entry into the labour market, specific welfare reforms mobilise coercive mechanisms including forms of welfare conditionality, limits on eligibility such as the 'work capability assessment', and restrictive 
reclassification of the disability category itself (Grover and Soldatic, 2013). These have parallels with the pejoratively value-laden notions of 'less eligibility' and 'stimulus to industry' of nineteenth century Poor Laws (Ferguson 2014).

A significant and growing proportion of disability benefit claimants, around $40 \%$, are people experiencing mental health difficulties (Viola and Moncrieff, 2016). As such, an important policy justification for this welfare reform agenda are claims that work is beneficial for mental wellbeing. 'Return to work' is increasingly vaunted as an essential route to recovery (Centre for Mental Health, 2016; The Mental Health Taskforce, 2016), though this has been disputed (Walker and Fincham, 2011). Such policy agendas have been accompanied by increasingly prominent government rhetoric purporting economic benefits of addressing epidemics of mental distress ( $\mathrm{DoH}, 2014)$.

Targeting benefit claimants with mental health needs with psychological interventions to engender labour market re-engagement can be traced back to the New Labour era (Black, 2008). Contiguous with the subsequent Work Programme of the Coalition government (Daguerre and Etherington, 2014), the strategy has evolved into the Health and Work Programme, which involves assimilation of employment advisers into psychological therapies services (Davies, 2016; The Mental Health Taskforce, 2016). Other related developments include co-location of mental health services and employment support, including placing DWP 'back to work' coaches in mental health centres or GP practices as part of a drive to ensure closer integration of the mandated outcomes of the NHS and employment services (DoH, 2014). Escalation of such practices has been termed 'psycho-compulsion' (Friedli and Stearn, 2015) and has been met with increasing resistance (Gayle, 2015). Amidst retrenchment of statutory mental health support, these developments suggest an emergent trend whereby therapeutic resources for claimants with mental distress are increasingly targeted towards welfare to work rather than mental health services (Pickles et al, 2016).

Consideration of the relationship between work and mental distress needs to recognise that the nature and experience of work is changing in the context of 
labour market transitions. Historically, capitalism has been subject to restructuring and, like other OECD economies, the UK has experienced a shift from manufacturing to a predominantly service and finance-led economy (Wren, 2013). A consequence is increasing intensity of contemporary work linked to technological and organizational changes (Felstead, et al, 2013) and declining autonomy and control for workers (Green, 2004). The relationship between work stress and mental health difficulties has been widely documented and identified as amongst the primary causes of sickness-related absence from work (HSE, 2015).

Notable are the particularly high levels of stress and diminished psychological wellbeing experienced within public sector roles in health, education and social care characterized by excessive demands and emotional labour (Johnson et al, 2005). The stress of work intensification and managerialist restructuring in public sector professions has been extensively documented (Jones, 2001; Harris, 2003). In mental health services, high levels of stress (Vyas and Luk, 2011) and low decisional latitude have precipitated emotional burnout, exhaustion and depersonalization (Evans et al, 2006).

As the preceding discussion suggests, the relationship between work and mental health is complex and context-dependent, with considerations such as levels of worker autonomy, control, bullying and workload intensity crucial to evaluating positive or negative impact (WHO, 2010; OECD, 2012; Walker and Fincham, 2011). It is increasingly apparent that as the service sector becomes the most common context for contemporary work, the routinized and repetitive practices and affective demands which characterise its labour process are producing newly predominant forms of impairment. Consequently mental distress is, arguably, the primary form of industrial injury in twenty-first century capitalism (Slorach, 2016). Just as earlier movements mobilised against the risks to physical health associated with deleterious conditions in traditional industries, so new forms of political struggle have the potential to challenge the mental health crisis produced by working conditions in those contemporary 'dark satanic mills': call centres or social work offices.

Thus, the policy agenda of recommodification impacts on welfare claimants, 
temporary workers and those in more stable employment through mechanisms of increased insecurity across these groups. In this instance the concomitant vulnerability of claimants also acts as a disciplinary mechanism on those in employment (Greer, 2016). Moreover, insecurity and anxiety for workers generated by the challenges of greater exposure to market forces and intensification of work are exacerbated by media and political discourses that 'manufacture uncertainty' around job stability (Doogan, 2009; Randall and McKeown, 2013). As these trends are contrary to the interests of trade union members this may compel resistance to labour market policies, engendering solidarities between claimant groups and workers (Greer, 2016). There are small but significant signs of such developments beginning to emerge.

\section{Political Strategy: shared interests and alliance-building}

We now turn to strategic considerations which, for Sedgwick, should be addressed by developing a political epistemology that "attend[s] to the specificities of the mental health field plus the conditions of possibility for future political work" (Cresswell and Spandler, 2009, p.142). The implication of this is that analytical and conceptual critique should always be located in a specific social and historical context in order to render its implications for emergent forms of political agency visible.

We have therefore elaborated, in the preceding section, a detailed ontology of neoliberal welfare, mental health system and labour market reform as a necessary basis for consideration of strategic possibilities. An important dimension of this is that the tendency for the re-commodification of the labour power of mentally distressed welfare claimants and intensification of work under neoliberalism to undermine the mental health of claimants and workers alike reveals shared material interests. Nonetheless, resolution of unfolding tensions between the proponents of neoliberalism and those negatively affected by its dynamics is ultimately a contingent political question (Barker and Lavalette 2015). While an unintended consequence of neoliberal reconfigurations of welfare and work is thus to create new conditions of possibility for alliance building, actual alliances are not inevitable, so questions of political strategy become crucial. 
In order to highlight specific political possibilities in the mental health context we draw upon Johnson's (2000) 'grammar of strategy', delineating characteristics of 'content, agency and form'.

\section{The grammar of strategy}

The first of the three strategic dimensions is that of content. We argue for a politics that rejects prioritisation of market demands in favour of the tangible and diverse needs of communities. The construction of need here is not oriented to minimal biological requirements but is concerned instead with creating the conditions for human flourishing and wider distributive justice. This politics serves to undermine the disciplinary power of the state insofar as it strengthens people's capacity for independent action (Johnson 2000). Moreover, this resonates with our emphasis upon the interaction between material and post-material concerns.

A second strategic consideration is that of form. The transitional approach to movement goals proposed by Sedgwick involves making demands that offer concrete social remedies in the present but which are underpinned by, and articulate, a new kind of social logic (Callinicos, 2003). Such transitional politics bridges social reforms and wider societal transformation, with elements of all three strategic transformative logics identified by Wright (2010: 303-5):

Ruptural transformations [associated with revolutionary socialism] envision creating new institutions of social empowerment through a sharp break within existing institutions and social structures [...] Interstitial transformations [associated with anarchism] seek to build new forms of social empowerment in the niches and margins of capitalist society [...] Symbiotic transformations [associated with social democracy] involve strategies in which extending and deepening the institutional forms of popular social empowerment simultaneously helps solve certain practical problems faced by dominant classes and elites.

However we argue that rather than regarding these as mutually exclusive, the strength of the transitional approach is that it integrates elements of all three, thereby transcending the limits of each logic taken in isolation, and offering a 
more fluid and credible strategic pathway to fundamental social emancipation.

A third and crucial consideration is agency, such that transformative demands are not constituted passively but actively across a range of contexts and scales. In the course of emancipatory struggles the capacity and political consciousness of collectivities is developed and strengthened. Strategic forms of agency are deeply relational sets of practices that cannot be properly comprehended through an individualizing lens (Krinsky and Barker, 2009). Instead, in the course of campaigning or organizing together in pursuit of shared objects, disparate constituencies (e.g. service user/survivors and trade unionists) have the potential to become a new collective subject. This collectivity enhances the 'strategic capacity' of movements, as trusting relationships are an important means to extend informational networks (Ganz, 2000) and draw on diverse knowledges and perspectives to inform campaigning (Krinsky, 2009). In this way strategic action constitutes a reflexive process of learning that implicates the identities, purposes and social relations of those involved, with agents who reshape and are themselves reshaped through such engagements (Krinsky and Barker, 2009).

The discussion will now turn to a more substantive exploration of these three dimensions of strategic grammar in relation to the possibilities and challenges of contemporary welfare and worker activism.

Strategy for mental health activism in the twenty first century

Consideration of the first strategic dimension, content, needs to be contextualized within an austerity agenda that, since the financial crisis of 2007-08, has been utilised by the UK government to realize further neoliberal transformation of the welfare state (Mendoza, 2015). This has had deeply damaging effects for mental health survivors, public sector workers and others (McKeown et al. 2013). A divisive rhetoric of 'skivers' and 'strivers' has been promulgated that seeks to drive a wedge between claimants and low-paid workers or those experiencing mental distress and those who are not (Garthwaite, 2011). Such dynamics are further amplified by the deleterious 
structural characteristics of contemporary work and mental health/welfare provision outlined above.

In the face of these onslaughts it is nonetheless possible to identify content within emergent strategic mobilisations of activists that challenges this agenda and articulates the diverse needs of people differently located within work and welfare contexts. An example of this is the orientation to both material and post-material needs in contemporary disability movement activism. While disabled people's movements in the 1980s and 1990s tended to focus on post-material concerns (in the form of legal and civil rights) somewhat eschewing transformative aims, in its recent incarnation it has played a leading role in redistributive struggles against austerity without marginalising recognition issues (Williams-Findlay, 2011; Slorach, 2016). Similarly, from the trade union movement there are early signs of an expanding conception of need that recognises the political implications for campaigning. For instance, the Trades Union Congress has recently aligned with a social model approach in its work around mental health (TUC, 2015; 2016).

We will now turn to the second consideration, form, beginning with an application of interstitial, symbiotic and ruptural logics and then linking this to the transitional approach. Elements of all three of Wright's (2010) transformative strategies are discernible in contemporary mental health activism in the UK. The interstitial includes pre-figurative forms of non-medical and non-coercive mental health support promoted in models such as Soteria (Mosher, 1999), or peer-led services such as the Leeds Survivor Led Crisis Service (Venner, 2009). Another expression of this is in forms of mutual aid offered to those experiencing mental distress for instance at the Occupy protests (Occupy Mental Health Project, 2012) or the emerging movement to offer low cost or free therapy to marginalised communities (Free Psychotherapy Network, no date). Insofar as such grassroots aid initiatives emerge from movement activity they might be regarded as forms of 'popular social work' (Lavalette, 2015). Sedgwick tended to be critical of earlier prefigurative experiments of this type, despite a more general affinity for prefiguration within his wider political epistemology (Proctor, 2016). In spite of 
his call for 'more and better' services, Proctor suggests he tended to focus implicitly on the struggle for 'more' state provision rather than elaborating 'better' modalities of support.

We regard counterposing the two to be problematic and, indeed, contrary to the spirit of Sedgwick's treatise. The concern to develop better forms of support has often been articulated in interstitial transformative practices, while the struggle for more services (in terms of funding increases or opposition to cuts) tends to be associated with a symbiotic logic. However interstitial and symbiotic elements cannot always be easily disentangled in actual struggles. To illustrate this, it might be argued that a symbiotic or defensive strategy has predominated in recent campaigns in mental health services facing funding cuts or closure (e.g. those described in Moth et al, 2015). This, we contend, would be a partial analysis, and more detailed consideration reveals interstitial elements. For instance, user and worker activist practices in the campaigns have pre-figured future aspirations in terms of both the leading role played in the campaigns by service users and how these actions have enhanced service users' involvement in subsequent service planning and operation (Moth et al, 2015). Similarly, the recognition of shared interests and contradictory positions between workers and service users opens up possibilities of more nuanced negotiation of identity issues and appreciation of the experience of mental health and service use or care work from each other's perspectives (McKeown et al 2014). For this reason we argue that, in practice, there tends to be fluidity in movement between defensive and innovative positions according to the exigencies of political circumstances.

However the possibilities for and boundary limits placed on interstitial and symbiotic transformative practices flow from the structural tendencies of contemporary capitalism. This necessitates a third, ruptural, strategy. Insofar as forms of mental distress are emergent from, exacerbated or mediated by the structural conditions of capitalist society, many of the most pressing challenges faced by both survivors and workers can be related to the organisation of labour and welfare regimes under this system. Consequently transcending these processes requires wholesale transformation of that social 
and economic structure. This strategic orientation is now visible in sections of the survivor movement such as Recovery in the Bin (RITB) who explicitly identify as anti-capitalist and have developed a class based analysis of the detrimental impact of neoliberalism on mental wellbeing (Recovery in the Bin, 2016; McKenna, 2016) as well as strands within radical practitioner networks such as SWAN (Ferguson, 2008) or the Critical Mental Health Nursing Network ${ }^{1}$.

We do not consider these three transformative logics to be mutually exclusive but instead to represent, at least potentially, different moments in a transitional approach. In the context both of defensive/symbiotic forms of social action (e.g. defending existing provision from cuts) and interstitial/innovative modes of support (e.g. mutual aid counselling for those unable to access statutory support) there is a challenge to extant arrangements and thereby the creation of spaces of resistance and oppositional logics. During instances of collective action structural barriers thereby become more visible offering the potential for generalization beyond the micro context of the specific service setting to wider systemic dynamics. Consequently, whether in defensive or innovative contexts, the central strategic consideration is how to foster a more fundamentally transformative purpose by stretching 'static' demands (i.e. those that merely seek to ameliorate conditions or restore earlier equilibrium) in a 'dynamic' or ruptural direction to foreground the need for broader societal transformation (Gindin, 2012). We offer brief examples to illustrate such stretching of demands in the concluding section of the paper.

Our third and final strategic dimension is agency. In the face of a 'divide and rule' social policy, the articulation of a politics of commonality and solidarity capable of respecting and valuing difference is an essential feature. A politics of this type, visible in cross-sectional alliances between the disabled people's movement, activist groups such as UK Uncut or Right to Work, welfare professionals and trade unionists, has been a characteristic feature of recent anti-austerity activism (Slorach, 2014, 2016; Scott 2014). A particularly

\footnotetext{
${ }^{1}$ https://criticalmhnursing.org/about-us/
} 
significant feature of the new disability movement is the pre-eminent role played within Disabled People Against Cuts (DPAC), Black Triangle and other groups by mental health service user/survivors and the ways in which mental health has become prominent within broader campaigns (Slorach 2016). Coalitions of service user/survivor activists and mental health workers have been central to campaigns against the rapid extension and roll out of forms of psycho-compulsion related to workfare (Recovery in the Bin, 2016; Steadman, 2015). Alignment of service user/survivor activists with trade unionists has also been a feature of a number of campaigns against service closures and cuts (Moth et al, 2015).

Trade union movement convergence is also beginning to emerge, demonstrated in developments such as the PCS (welfare workers') trade union's formal support for joint campaigning with DPAC and others (Slorach, 2014). Another example is the recent Welfare Charter initiative which has brought together trade unionists from PCS and Unite, activists from TUC Unemployed Workers' Centres and disability networks such as DPAC and Black Triangle at two conferences in $2015^{2}$ to organize campaigning against welfare reforms (Unite Community Leeds, 2015). Unison (public sector trade union) too has adopted policy resolutions committing to reciprocal organizing with service user/survivor groups, and most recently opposing forms of psycho-compulsion and seeking to defend workers who refuse to take part. We consider the emergence of such political 'cross-fertilisation' across divergent contexts of welfare service use and provision (Barker and Lavalette, 2015) and the development of collective subjectivity visible in these incipient relational configurations of activism and resistance to austerity offer possibilities for trade union and mental health user/survivor movement renewal (Moth et al, 2015; McKeown et al, 2014).

\footnotetext{
2 These took place on $27^{\text {th }}$ February and $31^{\text {st }}$ October 2015. More information available from: https://unitecommunityleeds.wordpress.com/2015/11/05/unitecommunity-report-from-social-security-summit/
} 
There are nonetheless significant sensitivities that need to be acknowledged in such processes of coalition building. Obstacles to solidarity have to be faced when forging worker-survivor alliances or across the disability field. We have written extensively about such impediments, and corollary possibilities, elsewhere. The obstacles most obviously include asymmetries of power between different groups and affinities for, and applicability of, different understandings of health, illness and disability (see McKeown, 2009; McKeown and Spandler, 2015; McKeown et al., 2014).

Such barriers, however, are, arguably, conjunctural rather than essential features of contemporary movement building and do not necessarily undermine the case for more grassroots cross-sectional alliances. Nonetheless a fundamentally democratic orientation is required within alliances of resistance, with sensitivity to extant power relations, in particular the potential for divisive stigmatising and oppressive constructions of both welfare claimants and mental health service user/survivors. We consider increased levels of organizing, resistance and struggle, however, to enhance the conditions of possibility for democratization and wider social change. Arguably, it is in such domains of intensified contestation that alternative conceptions of welfare and work, characterised by more equitable and participatory labour relations or democratised forms of therapy, tend to emerge (Spandler 2014). Indeed, the internal democracy of alliances and activism can itself herald a prefigurative, deliberative form that mimics the best of democratised, dialogic psychosocial support.

In summary, we have proposed a Sedgwickian epistemology that begins with political demands whose content asserts a wider conception of needs in their diverse manifestations across work and welfare contexts. We argue the form those demands take should be transitional. This recognizes that in the course of struggles over welfare there may be fluid movement between moments of defence of current arrangements and others pre-figuring novel forms of support. However in either case mobilization should articulate dynamic demands that stretch praxis beyond the limits of current support regimes and evoke valued possible welfare and societal futures. Moreover the agency for 
achieving such goals requires a politics of solidarity that, when embodied in alliances and relational organizing activism, gives a glimpse of the possibilities for more egalitarian relationships both in services and society. These potentials nonetheless require a fundamentally democratic ethos to ensure that unequal and oppressive social relations are not reproduced within crosssectional mobilisations. We will argue in the next and final section that the struggles to develop this new progressive politics of mental health would benefit from strategic tools to assist this process.

\section{Strategic tools for alliance building and democratizing struggles}

We consider that, in order to realize the political epistemology set out above, accessible activist tools could play a useful strategic role. However, to be consistent with this orientation such tools would require accessible political analysis of structural dynamics and associated challenges. Additionally, the content should indicate potentials for creating solidarities across diverse networks. For example, highlighting shared interests amongst various protagonists seeking change, identifying agents and constituencies to mobilise in the articulation of demands, and facilitating dialogue and deliberation towards these ends.

Arguably the SWAN Mental Health Charter launched in 2014 is an example of a tool that meets many of these criteria (SWAN Mental Health Charter, 2014). The Charter was an attempt to draw out some already emergent trends in contemporary resistance in mental health services, distil and amplify their radical potentials and make the case for deepening alliances, thus enhancing potentials for the attainment of social movement goals. It is clearly Sedgwickian in its argument that we need to defend services in the context of neoliberal austerity but, in doing so, harness emergent resistance to transform them. It also explicitly recognizes the inherent 'perils' in building alliances, in particular professional-user power imbalances, but argues that survivors and mental health workers have a shared interest in defending but also democratically reshaping collective welfare provision. The development process for the Charter sought to embody a democratic ethos with involvement from a wide range of constituencies including service 
users/survivors, practitioners and activists. In Liverpool, where we are based, the Charter has arguably provided the basis for discussion and constructive debates within and between local mental health activist groups, such as $\mathrm{SOS}^{3}$, reVision ${ }^{4}$ and SWAN, and trade unionists and other movement groups, to bridge different structural positions and ideological perspectives and construct a basis for shared forms of collective action (Moth et al, 2015).

Moreover the recent emergence of comparable interventions drawing together diverse coalitions around shared value positions, perspectives and political demands suggests an ongoing recognition of the value and necessity of such tools. Examples include the Welfare Charter noted earlier (Unite Community Leeds, 2015) and, in mental health activism, Recovery in the Bin's (RiTB) 20 Key Principles (Recovery in the Bin, 2016) and the Salford TUC PostAusterity Mental Health/Wealth Manifesto (House et al, 2016).

However, the impact of structural reforms to work and welfare outlined above has become increasingly apparent since the launch of SWAN's Charter. There is, consequently, a case for an updated intervention of this type. While any decision about whether to develop such a tool and the nature of its content is for survivor/worker/trade unionist movements to democratically determine, we conclude by offering brief suggestions. We advocate beginning with the twin inter-related demands of 'more and better welfare and support, less ${ }^{5}$ and better work'. This could focus on agitating for both decent wages for workers and higher levels of income for claimants. Similarly it might demand non-stigmatising, non-coercive, socially oriented and relational mental health services for service users/survivors, as well as mentally healthy workplaces with decent conditions and reduced workloads for workers. Such demands are both transitional and dynamic in form insofar as they address concrete practical needs but also suggest the narrow horizons of neoliberal policy proposals thereby inviting a transformative challenge to the status quo. By

\footnotetext{
${ }^{3}$ A service user led campaign against closure of mental health resource centres in Liverpool (see Moth et al, 2015)

${ }^{4}$ A campaigning organization of service user/survivors and allies in Liverpool advocating a social model of mental health

${ }^{5}$ The intention here is to demand reduced working hours and workloads
} 
articulating its content in this way, such a tool could play a necessary and important role in binding together diverse constituencies to create a collective subject oriented to joint activity and an ethic of solidarity. However while questions of content and form are important that of agency is also essential. Regardless of the strength of the arguments developed within them, the potential of such tools is only realised insofar as they are utilised by activists in the course of collective mobilisations and struggles.

\section{Conclusion}

We have argued for the contemporary relevance of a non-reductive historical materialist analysis and a renewed Sedgwickian epistemology to inform mental health activist strategy in the twenty-first century. The energy and commitment demonstrated by survivor activists, radical practitioners and wider movements in combination with the organizational strengths of the trade union movement can create new conditions of political possibility. These will be necessary not only to prevent the onslaught on existing welfare and mental health provision and the intensification of work but also to challenge toxic work environments and forge radically new ways of responding to mental distress. We hope that the kinds of struggles and alliances described in this paper will continue to emerge and deepen in the coming period for in such mobilisations lies the potential to realize Sedgwick's transformative vision for services and society. 


\section{References}

Barker, C. and Lavalette, M. (2015) Welfare Changes and Social Movements. In: Della-Porta, D. and Diani, M. (Eds) The Oxford Handbook of Social Movements. Oxford: Oxford University Press, pp.711-728

Boucher, G. (2008) The Charmed Circle of Ideology: A Critique of Laclau and Mouffe, Butler and Zizek. Melbourne, Aus: Re.Press

Black, C. (2008) Working for a Healthier Tomorrow: Dame Carol Black's Review of the Health of Britain's Working Age Population. London: TSO.

Callinicos, A. (2003) An Anti-Capitalist Manifesto. Cambridge: Polity

Centre for Mental Health (2016) Priorities for Mental Health: Economic report for the NHS England Mental Health Taskforce. London: Centre for Mental Health.

Creaven, S. (2007) Emergentist Marxism: Dialectical philosophy and social theory. London: Routledge.

Cresswell, M. and Spandler, H. (2009) Psychopolitics: Peter Sedgwick's legacy for the politics of mental health. Social Theory and Health, 7(2): 129-47 Daguerre, A. and Etherington, D. (2014) Welfare reform in the UK under the Conservative-led coalition government: ruptures and continuities. ESRC Working Paper 5. London: Middlesex University.

Davies, C. (2016) The Work and Health Programme - How innovative will delivery be? Learning and Work Institute [online] 19 February. Available from: http://www.learningandwork.org.uk/our-thinking/blog/work-and-healthprogramme-how-innovative-will-delivery-be (Accessed 30 March 2016) DoH (2014) Achieving Better Access to Mental Health Services by 2020. London: DoH.

Doogan, K. (2009) New Capitalism? The Transformation of Work. Cambridge: Polity Press. 
Edwards, G. (2004) Habermas and social movements: what's 'new'? The Sociological Review, 52 (s1), pp. 113-130

Esping-Andersen, G. (1990) Three Worlds of Welfare Capitalism. Cambridge: Polity Press.

Evans, S, Huxley, P, Gately, C, Webber, M, Mears, A, Pajak, S, Medina, J, Kendall, T. and Katona, C. (2006) Mental health, burnout and job satisfaction among mental health social workers in England and Wales. The British Journal of Psychiatry, 188 (1) 75-80

Felstead, A., Gallie, D., Green, F. and Inanc, H. (2013) Work Intensification in Britain: First Findings from the Skills and Employment Survey 2012, London: Institute of Education.

Ferguson, I. (2008) Reclaiming Social Work: Challenging Neoliberalism and Promoting Social Justice. London: Sage.

Ferguson, I. (2014) Can the Tories abolish the welfare state? International Socialism, 2(141): 13-36

Free Psychotherapy Network (no date) Free Psychotherapy Network [online] Available from: https://freepsychotherapynetwork.com [accessed May 30th 2016]

Friedli, L. and Stearn, R. (2015) Positive affect as coercive strategy: conditionality, activation and the role of psychology in UK government workfare programmes. Medical Humanities 41(1): 40-7

Ganz, M. (2000). Resources and resourcefulness: Strategic capacity in the unionization of California agriculture, 1959-1966. American Journal of Sociology, 105: 1003-62

Garthwaite, K. (2011) 'The Language of Shirkers and Scroungers?' Talking about IIIness, Disability and Coalition Welfare Reform. Disability and Society 26 (3): 369-372

Gayle, D. (2015) Mental health workers protest at move to integrate clinic with jobcentre. The Guardian [online] 26 June. Available from:

http://www.theguardian.com/society/2015/jun/26/mental-health-protest-clinicjobcentre-streatham (accessed 1 April 2016) 
Gindin, S. (2012) 'Rethinking unions, registering socialism'. In: L. Panitch, G. Albo and V. Chibber (Eds.) Socialist Register 2013: The Question of Strategy. Pontypool: Merlin Press, pp.26-51

Greer, I. (2016) Welfare reform, precarity and the re-commodification of labour. Work, Employment and Society, 30(1): 162-173

Green, F. (2004) Work Intensification, Discretion, and the Decline in WellBeing at Work. Eastern Economic Journal, 30(4): 615-625

Grover, C. (2003) New Labour, welfare reform and the reserve army of labour. Capital and Class, 79: 17-24

Grover, C. (2015) Commodification, disabled people, and wage work in Britain. Canadian Journal of Disability Studies, 4(2): 106-131

Grover, C. and Piggott, L. (2005) Disabled people, the reserve army of labour and welfare reform. Disability \& Society, 20(7): 705-717, DOI:

$10.1080 / 09687590500335683$

Grover, C. and Soldatic, K. (2013) Neoliberal restructuring, disabled people and social (in)security in Australia and Britain. Scandinavian Journal of Disability Research, 15(3): 216-32

Harris, J. (2003) The Social Work Business. London: Routledge.

House, R., Moth, R., Porteous, D. and Jamieson, G. (2016) Mental Health Beyond Austerity: A "Mental Wealth" approach to post-austerity policymaking. Self and Society, xx, pp.xx

HSE (2015) Work related Stress, Anxiety and Depression Statistics in Great Britain 2015. London: Health and Safety Executive. Available from: http://www.hse.gov.uk/statistics/causdis/stress/stress.pdf Johnson, A. (2000) 'The Making of a Poor People's Movement: A Study of the Political Leadership of Poplarism 1919-25'. In: Lavalette, M. and Mooney, G. (eds) Class Struggle and Social Welfare. London: Routledge, pp. 96-116 Johnson, S, Cooper, C, Cartwright, S, Donald, I, Taylor, P and Millet, C. (2005) The Experience of Work-Related Stress Across Occupations. Journal of Managerial Psychology 20 (2), 178-187 
Jones, C. (2001) Voices From the Front Line: State Social Workers and New Labour. British Journal of Social Work, 31(4): 547-562

Krinsky, J. (2009) Missing the Marx: Toward a Dialectical, Materialist Interpretation of Social Movements. Unpublished paper from Politics and Protest Workshop, City University New York, February 19.

Krinsky, J. (2013) 'Marxism and the Politics of Possibility: Beyond Academic Boundaries'. In: C. Barker, L. Cox, J. Krinsky and A. Gunvald Nilsen (eds.) Marxism and Social Movements. Leiden: Brill, pp. 103-121

Krinsky J. and Barker, C. (2009) 'Movement Strategizing as Developmental Learning: Perspectives from Cultural-Historical Activity Theory'. In: H. Johnston (Ed) Culture, Social Movements, and Protest. Farnham: Ashgate, pp.209-225

Laclau, E. and Mouffe, C. (2001) Hegemony and Socialist Strategy: Towards a Radical Democratic Politics. 2nd Edition. London: Verso.

Lavalette, M. (2015) Once more on 'popular social work': a reply to Des McDermott. Critical and Radical Social Work, 3(3):425-31

McKenna, D. (2016) Welfare Reforms and Mental Health. Speech at "Welfare Reforms and Mental Health - Resisting Sanctions, Assessments and Psychological Coercion" Conference, 5 March 2016. Available from: https://recoveryinthebin.org/2016/03/10/welfare-reforms-and-mental-healthresisting-sanctions-assessments-and-psychological-coercion-by-denisemckenna-mental-health-resistance-network-mhrn/ (Accessed 1 April 2016) McKeown, M. (2009) Alliances in action: opportunities and threats to solidarity between workers and service users in health and social care disputes. Social Theory and Health, 7, 148-169.

McKeown, M., Jones, F. \& Spandler, H. (2013) Challenging austerity policies: democratic alliances between survivor groups and trade unions. Mental Health Nursing, 33, 6, 26-29.

McKeown, M., Cresswell, M. \& Spandler, H. (2014) Deeply engaged relationships: alliances between mental health workers and psychiatric survivors in the UK. In B. Burstow, B. A. LeFrancois and S. L. Diamond (eds) 
Psychiatry disrupted: theorizing resistance and crafting the revolution. Montreal, QC: McGill/Queen's University Press.

McKeown, M. \& Spandler, H. (2015) Solidarity across difference: organising for democratic alliances. In H Spandler, J Anderson \& B Sapey (eds) Distress or disability? Mental Health and the Politics of Disablement. Policy Press, Bristol.

Melucci, A. (1996) Challenging Codes: Collective action in the information age, Cambridge: Cambridge University Press

Mendoza, K. (2015) Austerity: The Demolition of the Welfare State and the Rise of the Zombie Economy. Oxford: New Internationalist.

Mosher, L.R. (1999) Soteria and Other Alternatives to Acute Psychiatric Hospitalization: A Personal and Professional Review. Journal of Nervous and Mental Disease, 187(3): 142-149

Moth, R., Greener, J. and Stoll, T. (2015) Crisis and resistance in mental health services in England, Critical and Radical Social Work, 3(1):89-101 Occupy Mental Health Project (2012) Mindful Occupation: Rising Up Without Burning Out: Rising Up Without Burning Out . Richmond, VA: Mindful Occupation.

OECD (2012) Sick on the Job? Myths and Realities about Mental Health and Work, Mental Health and Work. Paris: OECD Publishing

Pickles, C., Holmes, E., Titley, H. and Dobson, B. (2016) Working welfare: a radically new approach to sickness and disability benefits. London: Reform.

Pilgrim, D. (2013) The Failure of Diagnostic Psychiatry and some prospects of Scientific Progress Offered by Critical Realism. Journal of Critical Realism 12(3): 336-358

Pilgrim, D. (2016) Peter Sedgwick, proto-critical realist? Critical and Radical Social Work, 4(3)

Proctor, H. (2016) Lost Minds: Sedgwick, Laing and the politics of mental illness. Radical Philosophy, 197, pp.36-48 
Randall, D. and McKeown, M. (2013) Failure to care: nursing in a state of liquid modernity? Journal of Clinical Nursing, 23: 766-767

Recovery in the Bin (2016) Recovery in the Bin - 20 Key Principles. Recovery in the Bin [online]. Available from https://recoveryinthebin.org/recovery-in-thebin-19-principles/ (accessed 20 April 2016)

Scott, B. (2014) The Broadest Shoulders? Disabled People and "Welfare Reform". Concept, 5(1), 10. Retrieved from:

http://concept.lib.ed.ac.uk/index.php/Concept/article/view/248 (Accessed 25 March 2016)

Sedgwick, P, 1972, Who's mad - you or the system?, Socialist Worker, 5 February, https://www.marxists.org/archive/sedgwick/1972/02/family.htm

Sedgwick, P. (1982a) 'Anti-psychiatry from the sixties to the eighties', in W.R. Gove (ed.) Deviance and Mental IIIness, Beverly Hills: Sage, pp.199-224

Sedgwick, P. (1982b) Psycho Politics. London: Pluto.

Sedgwick, P. (1987) Psycho Politics. $2^{\text {nd }}$ Ed. London: Pluto.

Sedgwick, P. (2015) Psycho Politics. London: Unkant.

Slorach, R. (2014) Out of the shadows: disability movements. Critical and Radical Social Work, 2(2): 159-174

Slorach, R. (2016) A Very Capitalist Condition: A history and politics of disability. London: Bookmarks.

Spandler, H. (2014) Letting madness breathe? Critical challenges facing mental health social work today. In: Weinstein, J. (ed) Mental Health. Bristol: Policy Press, pp.29-38

Steadman, K. (2015) Betting the budget on mental health? The Work Foundation, Lancaster University [online]. Available from:

http://www.theworkfoundation.com/blog/2481/Betting-the-budget-on-mentalhealth [accessed 16 March 2016]

Steinmetz, G. (1994) Regulation Theory, Post-Marxism, and the New Social Movements. Comparative Studies in Society and History, 36(1): 176-212 
SWAN (2014) A Charter for Mental Health launched by the Social Work Action Network (SWAN), UK, Critical and Radical Social Work, 2, 3, 411-12

The Mental Health Taskforce (2016) The Five Year Forward View for Mental Health. London: NHS England.

TUC (Trades Union Congress) (2015) Mental Health and the Workplace. London: TUC.

TUC (2016) Equality and mental health in an age of austerity. London: TUC. Unite Community Leeds (2015) Unite Community Report from Social Security Summit. Unite Community Leeds [online]. Available from:

https://unitecommunityleeds.wordpress.com/2015/11/05/unite-communityreport-from-social-security-summit/ [accessed 16 March 2016].

Venner, F. (2009) Leeds Survivor Led Crisis Service - survivor-led philosophy in action. A Life in the Day, 13(2), pp.28 - 31

Viola, S. and Moncrieff, J. (2016) Claims for sickness and disability benefits owing to mental disorders in the UK: trends from 1995 to 2014. British Journal of Psychiatry Open, 2(1): 18-24

Vyas, L., \& Luk, S. (2011) Frazzled care for social workers in Hong Kong: Job stress circumstances and consequences. 54 (6), 832-85

Walker, C. and Fincham, B. (2011) Work and the mental health crisis in Britain. Chichester: John Wiley \& Sons.

White, M. (2015) Cinderella's suitors line up to claim mental health in their political manifestos. Health Service Journal [online]. Available from:

http://www.hsj.co.uk/comment/cinderellas-suitors-line-up-to-claim-mentalhealth-in-their-political-manifestos/5078349.fullarticle (Accessed 3 April 2016) WHO (2010) Mental Health and Well-being at the Workplace Protection and Inclusion in Challenging Times. Copenhagen: World Health Organization Europe.

Williams-Findlay, R. (2011) 'Lifting the lid on disabled people against cuts', Disability \& Society 26(6):773-78 
Wren, A. (2013) The political economy of the service transition. Renewal: A Journal of Social Democracy, 21(1): 67-76

Wright, E. O. (2010) Envisioning Real Utopias. London: Verso. 